\title{
Adiamento e suspensão de sentido em Grande sertão: veredas - do pacto demoníaco
}

Claudia Campos Soares"

\section{Resumo}

Riobaldo, o narrador-protagonista de Grande sertão: veredas, demonstra, ao longo de toda a sua narrativa, grande preocupação com a questão do mal e com a figura do demônio; e afirma, mais de uma vez, que pode falar do assunto com particular propriedade. Durante boa parte do livro, entretanto, ele não explicita o principal motivo de $o$ assunto interessa-lo tanto, nem o que lhe permite afirmar que é particularmente apto a falar sobre ele. Riobaldo propõe mistérios e, ao modo das narrativas de suspense, adia o seu esclarecimento. Diferentemente dessas narrativas, entretanto, quando ele enfim narra o episódio que teria motivado suas preocupações (o duvidoso pacto demoníaco), o "esclarecimento" que se dá não é suficiente para responder às questões que o inquietam. E coloca outras. Assim, o caminho da elucidação acaba levando à incerteza e à indeterminação.

Palavras-chave: Grande sertão: veredas. Guimarães Rosa. Adiamento e suspensão de sentido. Pacto demoníaco. Indeterminação.
Uma questão absolutamente recorrente em Grande sertão: veredas, como se sabe, é a da presença do mal no mundo, que Riobaldo, o narrador-protagonista do livro, associa ao demônio, acorde às crenças de seu meio. Ao longo de todo o livro, evidencia-se essa sua preocupação obsessiva: o ex-jagunço está sempre refletindo sobre a natureza do mal, sua origem, seus limites, suas motivações, manifestações, consequências...; e sobre a sua encarnação, ou não, na figura do demônio.

O assunto aparece logo nas primeiras palavras do livro ${ }^{1}$ e é absolutamente recorrente ao longo de todo ele, revelando-se um motivo de grande inquietação para Riobaldo - que, também logo no início da narrativa, salienta o caráter pessoal de seu interesse no assunto: "Tem diabo nenhum. Nem espírito. Nunca vi. Alguém devia de ver, então era

Professora da Faculdade de Letras da UFMG. Doutora pela Universidade de São Paulo. E-mail: claudiasoares3107@gmail.com

Data de submissão: set. 2020 - Data de aceite: nov. 2020 http://dx.doi.org/10.5335/rdes.v16i3.10382 
eu mesmo, este vosso servidor. Fosse lhe contar..." (10, grifo meu). Segundo Riobaldo, portanto, ele fala por experiência própria, mas não revela, nesse momento, o que lhe permitiu tal afirmação.

À medida que a narrativa prossegue, vão-se mostrando os motivos de suas preocupações. No passado, Riobaldo fora jagunço e, como tal, praticou atos atrozes, tendo, por exemplo, estuprado mulheres e matado pessoas, muitas pessoas. É por isso que, em suas palavras, "quem de si de ser jagunço se entrete, já é por alguma competência entrante do demônio" (10). Em seu passado de lutas, o ex-jagunço conviveu com homens capazes das "maiores ruindades calmas que já se viu" (12), como o Hermógenes, em quem identifica uma maldade pura e sem razão - a "inocência daquela maldade" (234), diz a certa altura. É o que se percebe, por exemplo, nesta descrição:

Mas o Hermógenes era fel dormido, flagelo com frieza. [...]. Ele gostava de matar, por seu miúdo regozijo. Nem contava valentias, vivia dizendo que não era mau. Mas, outra vez, quando um inimigo foi pego, ele mandou: - 'Guardem este.' Sei o que foi. Levaram aquele homem, entre as árvores duma capoeirinha, o pobre ficou lá, nhento, amarrado na estaca. O Hermógenes não tinha pressa nenhuma, estava sentado, recostado. A gente podia caçar a alegria pior nos olhos dele. Depois dum tempo, ia lá, sozinho, calmoso? Consumia horas, afiando a faca. Eu ficava vendo o Hermógenes, passado aquilo: ele estava contente de si, com muita saúde. Dizia gracejos. (170-171).
O comportamento do Hermógenes, o regozijar-se com a dor alheia, provoca perplexidade e inquietação em Riobaldo - que, apesar de ter feito o que fez, não é infenso a problemas de consciência, não tem a "inocência da maldade" que permite ao Hermógenes não se abalar com o sofrimento que provoca - e, mais que isso, sentir prazer com ele. Em Riobaldo, ao contrário, o comportamento do outro provoca perturbação e repugnância. É o que se observa na continuação do trecho citado:

Eu não queria olhar para ele, encarar aquele carangonço; me perturbava. Então, olhava o pé dele - um pé enorme, descalço, cheio de coceiras, frieiras de remeiro do rio, pé-pubo. Olhava as mãos. Eu acabava achando que tanta ruindade só conseguia estar naquelas mãos, olhava para elas, mais, com asco. (171).

Correlatos à "ruindade" do Hermógenes, seus pés e suas mãos eram disformes e asquerosos. ${ }^{2}$ Vale lembrar que, segundo o dicionário Aulete Digital, "pubo" é sinônimo de podre, putrefato; e "carangonço", no sertão, é um outro nome para o escorpião, cuja natureza, conforme a conhecida fábula, o impele a picar, ainda que isso leve a sua própria morte.

Riobaldo, entretanto, tem natureza diversa: arrependeu-se dos estupros que cometeu ainda nos tempos da jagunçagem, quando, ao submeter uma mulher à força: 
[...] essa se sujeitou fria estendida, para mim ficou de pedras e terra. Ah, era que nem eu nos medonhos fosse - e, o senhor crê? - a mocinha me aguentava era num rezar, tempos além. Às almas fugi de lá, larguei com ela o dinheiro meu, eu mesmo roguei pragas. Contanto que nunca mais abusei de mulher (173).

Além disso, apesar de participar dele, Riobaldo reprova o modo de vida jagunço, dedicado à prática da violência. Ele não se sentia identificado ao grupo, questionava seus valores e métodos e, pelo menos inicialmente, mostrava-se muito perturbado com eles. É o que se evidencia, por exemplo, no episódio em que seu bando aprisiona um inimigo (na época os inimigos eram os "bebelos") que, conforme as regras do grupo, devia ser morto.

Cocei os olhos, eu queria saber e não saber. Sabia nem o nome, como se chamava o rapaz, que ia morrer, assim no meio de toda boa ordem, por necessidade nossa - porque, se solto, ele tornava a se juntar com os outros, dar relatórios. Vim para a beira do córrego. Vendo como levavam o rapaz, como ele caminhava normal, seguindo para aquilo com seus dois pés. Essa injustiça não podia ser! [...]. Ânsia de dó, apalpei o nó na goela, ardi. Aquilo fosse sonho mero, então só sonho; ou, não fosse, então eu carecia de uma realidade no real, sem divago! Ajoelhei na beirada, debrucei, bebi água com encostando a boca, com a cara, feito um cachorro, um cavalo. A sede não passava, minha barriga devia de estar inchada, igual a de um sapo, igual um saco de todo tamanho. A umas cem braças para cima, onde o córrego atravessava a capoeira, estavam esfaqueando o rapaz, e eu espiava para a água, esperando ver vir misturado o sangue vermelho dele que eu não era capaz de deixar de beber. Acho que eu estava com uma febre (240-241).
Em outro momento, afirma o ex-jagunço: "Então, eu era diferente de todos ali? Era. Por meu bom. Aquele povo da malfa, no dia e noite de relaxação, brigar, beber, constante comer. - 'Comeu, lobo?' E vozear tantas asneiras..." (172). Em "malfa", conjuga-se o sentido de "mafra", segundo o dicionário Aulete Digital, "multidão de povo, turba, gente ordinária"; e de "malta", onde o sentido se completa: "grupo de desordeiros e vagabundos”, segundo o mesmo dicionário. ${ }^{3}$

Riobaldo, como se vê, constrói uma visão muito negativa do grupo de que faz parte e demonstra sentir-se mal com seu modo de viver. Essa desaprovação, ou reprovação, da vida jagunça também é apresentada como um dos motivos que o teriam levado a deixar o bando de Zé Bebelo - que, na época, lutava contra os "ramiros" e a favor do governo: "Fugi. De repente, eu vi que não podia mais, me governou um desgosto. Não sei se era porque eu reprovava aquilo: de se ir, com tanta maioria e largueza, matando e prendendo gente, na constante brutalidade" (135). Apesar da dúvida sobre se este teria sido realmente o motivo de ter ele deixado o bando ("não sei se era porque...”), a afirmação denuncia o conflito moral e/ou ético.

Além desse conflito, mas diretamente relacionado a ele, há um outro motivo, ainda mais forte, para o ex-jagunço estar sempre retornando, obsessivamente, à questão do mal e do demônio: ele pode, 
nos tempos da jagunçagem, ter realizado o famigerado pacto com o "Cujo". Num dado momento de sua vida, pelo menos, dispôs-se a fazê-lo. E tomou as providências devidas para tal, obedecendo as regras do ritual conhecidas no sertão: dirigiu-se a uma encruzilhada (a das Veredas Mortas) à meia-noite, invocou o demônio e "figurou no espírito" um objetivo: "Acabar com o Hermógenes! Reduzir aquele homem!...” (421). Agora, no momento da narração, já velho e "declinando para não-ezas", ${ }_{4}^{4}$ aflige-se também com o destino de sua alma:

Hoje em dia, não me queixo de nenhuma coisa. Não tiro sombras dos buracos. Mas, também, não há jeito de me baixar em remorso. Sim, que só duma coisa. E dessa, mesma, o que tenho é medo. [...]. Minha vida não deixa benfeitorias. Mas me confessei com sete padres, acertei sete absolvições. No meio da noite eu acordo e pelejo para rezar (64).

Riobaldo afirma ter remorso "só duma coisa". Tem remorso dela e de mais nada, o que realça a importância da tal "coisa" para ele. A seguir, ele retifica: não é propriamente remorso, mas medo, o que ele sente em relação a ela. Muito medo, pois, por causa dela, o ex-jagunço sentiu necessidade de se confessar não com um, mas com sete padres; e acorda à noite para tentar rezar. Em outro momento, afirma:

Eu cá, não perco ocasião de religião. Aproveito de todas. Bebo água de todo rio... Uma só pra mim é pouca, talvez não me chegue. Rezo cristão, católico, embrenho a certo; e aceito as preces de compadre meu Que- lemém, doutrina dele, de Cardéque. Mas, quando posso, vou no Mindubim, onde um Matias é crente, metodista: a gente se acusa de pecador, lê alto a Bíblia, e ora, cantando hinos belos deles. [...]. Olhe: tem uma preta, Maria Leôncia, longe daqui não mora, as rezas dela afamam muita virtude de poder. Pois a ela pago, todo mês - encomenda de rezar por mim um terço, todo santo dia, e, nos domingos, um rosário. [...]. E estou, já mandei recado para uma outra, do Vau-Vau, uma Izina Calanga, para vir aqui, ouvi de que reza também com grandes meremerências, vou efetuar com ela trato igual. Quero punhado dessas, me defendendo em Deus, reunidas de mim em volta... Chagas de Cristo! (16).

Riobaldo, como se vê, sente necessidade de utilizar todos os meios possíveis para "aquietar" um "temer de consciência" (15) que, entretanto, ele não explicita durante boa parte da narrativa. $\mathrm{O}$ ex-jagunço chama a atenção, por diversas vezes, para algo que ele não diz; vale dizer, ele anuncia, mas não enuncia. Só a partir da página $419^{5}$ (mais de dois terços do livro idos, aproximadamente), começará a relatar o (não)acontecimento, o pacto em questão, que, tudo indica, motivou o seu remorso-medo. $\mathrm{O}$ que Riobaldo faz, portanto, é propor um mistério e adiar sua revelação, criando uma atmosfera de suspense - segundo David Lodge (2010, p. 23), "efeito que se obtém ao se fazer perguntas e adiar as respostas". As estratégias textuais de que se utiliza o suspense objetivam "despertar, manter e incrementar o interesse pela obra. Em regra, induzem o receptor 
a aguardar com impaciência o remate da acção que assim o prende" (CEIA, 2019).

É isso o que se constrói em Grande sertão: veredas no que se refere à relação de Riobaldo com a questão do mal/demônio. Jogando com as expectativas de seu interlocutor-ouvinte (e, consequentemente, com as do leitor), ${ }^{6}$ o ex-jagunço procura suscitar essa disposição mental de interesse e desejo de esclarecimento.

$\mathrm{Na}$ tradição das narrativas que se utilizam de estratégias para atingir o suspense, entretanto, em algum momento, o esclarecimento se dá - e, com ele, o alívio da tensão da satisfação prometida e postergada. No Grande sertão, todavia, isso não acontece, pois a "elucidação" não satisfaz o desejo de conhecimento pleno que a narrativa alimentava, antes reafirma o mistério, como se discute a seguir.

Como costuma acontecer nos rituais iniciáticos, Riobaldo sentiu no corpo os efeitos da tenebrosa noite passada na encruzilhada das Veredas Mortas: logo depois, é acometido por uma "forte sede" e um frio terrível, desproporcional em relação à temperatura que fazia no momento:

Eu tinha tanto friúme assim mesmo me requeimava forte sede. Desci, de retorno, para a beira dos buritis, aonde o pano d'agua. [...]. $\mathrm{E}$ a água até nem não estava de frio geral: não apalpei nela a mornidão que devia-de, nos casos de frio real o tempo estar fazendo. Meu corpo era que sentia um frio, de si, frior de dentro e de fora, no me rigir. Nunca em minha vida eu não tinha sentido a solidão duma friagem assim. E se aquele gelado inteiriço não me largasse mais (423).
Depois, sentiu-se exausto, esgotado: "tinha derreado as forças comuns do meu corpo" e "Soporado, fiquei permanecendo. [...]. Eu jazi mole no chão" (423). Quando se recupera suficientemente e retorna ao convívio dos companheiros, um deles pergunta a Riobaldo se pegara maleita, pois ele tremia muito. E o jagunço mesmo se sente diferente:

E, o que eu fazia, era que eu pensava sem querer, o pensar de novidades. Tudo agora reluzia com clareza, ocupando minhas ideias, e de tantas coisas passadas diversas eu inventava lembrança, de fatos esquecidos em muito remoto, neles eu topava outra razão; sem nem que fosse por minha própria vontade. Até eu não puxava por isso, e pensava o qual, assim mesmo, quase sem esbarrar, o todo tempo (424).

Riobaldo sente a visão e a memória mais aguçadas, e hoje, relembrando o momento, percebe que perdeu o controle de si mesmo, pois diz que essas "novidades" "ocupavam suas ideias" a despeito de sua "própria vontade", como se agora não fosse mais (e como se anteriormente o fosse), senhor de seus pensamentos.

Dá-se também uma grande transformação no comportamento do então jagunço. Afirma Riobaldo que, "aos poucos, entrava numa alegria estrita” (424) e, antes retraído e discreto - "peixe de grotão” (p. 187), em suas próprias palavras, passa a ter "enjoo de toda pasmacez" (426): "eu me espiritava só para arrelias e inconveniências” (427). 
A transformação é percebida imediatamente por seô Habão, o grande proprietário de terras e Capitão da Guarda Nacional cuja fazenda os jagunços, sob o comando de Zé Bebelo, ocuparam durante alguns dias quando, ao fugir, ao mesmo tempo, dos soldados do governo e do Hermógenes, acabaram perdidos nos confins do sertão. A certa altura, encontraram uma fazenda abandonada e ali se acomodam. Daí a alguns dias, apareceu por lá o proprietário, seô Habão. Riobaldo não simpatizou com ele desde o primeiro momento: "um homem assim [...] era para se querer longe da gente; [...] porque ele era de raça tão persistente, no diverso da nossa, que somente a estância dele, em frente, já media, conferia e reprovava" (414). Seô Habão era "homem só vendido ao dinheiro e ao ganho" (430). Ele "vigiava os traços simples do arredor, não perdendo azo de reparar em todas as coisas, como era que estavam em que pé. Olhares de dono" (412); e "dava balanço, inquiria, e espiava gerente para tudo, como se até do céu, e do vento suão, homem carecesse de cuidar comercial" (413).

O contraste entre o modo de ser "comercial" de seô Habão e o dos jagunços se explicita quando o fazendeiro diz a Zé Bebelo, que comandava o bando na ocasião, que não tinha dinheiro no momento, mas podia provê-lo de farta quantia se o chefe jagunço o acompanhasse até outra propriedade sua. A resposta vem nos seguintes termos:

[...] com seus modos guerreiros, Zé Bebelo abriu um gesto, à fidalgamente, nem deixando o outro estipular:

- Ah, isso não, patrício meu amigo, he, mas absolutamente! A gente não é gente da desordem... E favor, de sobra, nós já devemos ao senhor pela pousada em suas terras e pelas cabeças de gado de sua posse, que temos carneado, por precisão de sustento... (413).

Em oposição aos "modos guerreiros" e ao gesticular "à fidalgamente" de Zé Bebelo, seô Habão, na visão de Riobaldo, não tem "glória nenhuma" (413), e tem "miúdo comportamento" (412).

Vale lembrar também que Zé Bebelo ocupou a fazenda - por "mais de mês"! (411) - e matou as reses sem autorização do proprietário, que, "manso e mansoso" (413), não se opõe - talvez porque não tenha opção; a outra possibilidade seria enfrentar o bando de jagunços, contra quem lutaria em absoluta desigualdade de condições -; ao contrário: "O homem depressa pronunciou que tinha prazer naquilo, que sua boiada toda estava às ordens, mas, como por uma regra, perguntou assim mesmo quantas cabeças, mais ou menos, a gente já tinha consumido" (413). Seô Habão não tem como se opor ao grupo, mas continua a vigiar, a inquirir, a "dar balanço".

Riobaldo diz não cultivar raiva do outro, mas um "desgosto" (415), que se acentua quando percebe que o fazendeiro queria: 
[...] que nós, Zé Bebelo, eu, Diadorim, e todos os companheiros, que a gente pudesse dar os braços, para capinar e roçar, e colher, feito jornaleiros dele. Até enjoei. Os jagunços destemidos, arriscando a vida, que nós éramos; e aquele seô Habão olhava feito o jacaré no juncal: cobiçava a gente para escravos! (415).

Percebemos no trecho a indignação de Riobaldo diante do não reconhecimento pelo fazendeiro "vendido ao dinheiro e ao ganho" da superioridade dos jagunços na escala social do sertão. Como observou Candido (1995, p. 164), "o risco e a aventura dão ao jagunço uma espécie de dignidade não encontrada em fazendeiros estadonhos, solertes aproveitadores da situação, que o empregam para seus fins ou o exploram para maior luzimento da máquina econômica". A "fidalguia" do jagunço rosiano também provém, como observou ainda Candido (1983, p. 302), da contaminação do sertão pelo idealismo dos "padrões medievais". ${ }^{7}$ É, portanto, uma desonra considerá-los possíveis trabalhadores braçais.

Riobaldo retribuirá na mesma proporção mais adiante. $\mathrm{O}$ encontro seguinte com seô Habão, depois do possível pacto, é bastante diferente.

O fazendeiro voltava à fazenda montado no belo cavalo que, na visita anterior, impressionara fortemente Riobaldo: "o cavalo - esse me entusiasmou: era um animal gateado, grande, com imponência e todo brio, de rabejo vasto; e mais tarde o senhor verá o que ele era" (412).
Antes de prosseguir na discussão do episódio, vale chamar a atenção para o final da frase: "mais tarde o senhor verá o que ele era". Vemos, aqui, empregada, mais uma vez, a técnica da proposição de perguntas e adiamento de respostas que alimenta o interesse do leitor. No final do parágrafo, ele volta a utilizá-la: "Bem, dele depois lhe conto" (412).

Nessa segunda visita à fazenda:

[...] o animal dele (de seô Habão), o gateado formoso, deu que veio se esbarrar ante mim. Foi o seô Habão saltando em apeio, e ele se empinou: de dobrar os jarretes e o rabo no chão; o cabresto, solto da mão do dono, chicoteou alto no ar. - "Barzabu!" - xinguei. E o cavalão, lão, lão, pôs pernas para adiante e o corpo para trás, como onça fêmea no cio mor. Me obedecia. [...]. O seô Habão estava ali, me desentendeu nos olhos. Ele ficou a vermelho. Mas eu acho que, homem só vendido ao dinheiro e ao ganho, às vezes são os que percebem primeiro o atiço real das coisas, com a ligeireza mais sutil. Ele não gaguejou. Melhor me disse: - "Se este praz ao senhor... Se ele praz ao senhor... Lhe dou, amigavelmente, com bom agrado: assim como ele está, moço, ele é seu...” (430).

Diante da extraordinária reação do cavalo diante de Riobaldo e da forma como o jagunço o domina - gritando "Barzebu" - ${ }^{8}$ seô Habão, que "percebe o atiço real das coisas, com a sutileza mais sutil", identifica no jagunço uma "transformação pesável" (109), para usar palavras de Riobaldo, ${ }^{9}$ e o presenteia com o belo animal, cujo novo dono chamará Siruiz (430). Dá-lho a ele, um (ainda) simples jagunço, ao invés de prestigiar Zé Bebelo, com o "generoso" obséquio 
(431-432). Trata-se de uma indicação de que o chefe não o será por muito tempo.

Um pouco mais adiante, Riobaldo, até então refratário à ideia de comandar o bando - já tinha se posicionado firmemente contra isso quando fora indicado pelo olhar moribundo de Medeiro Vaz (79) -, enfrentará Zé Bebelo para tomar-lhe o posto e o exercerá agindo da mesma forma extravagante que passou a caracterizá-lo depois de ter invocado o demo nas Veredas Mortas. Diadorim, observador privilegiado dessa mudança, formulou-a nos seguintes termos:

Repuno: que você está diferente de toda pessoa, Riobaldo... Você quer dansação e desordem... [...]. E o que está demudando, em você, é o cômpito da alma - não é razão de autoridade de chefias... (468).

Em outro momento, Diadorim diz a Riobaldo que "alguém lhe botara "malefício" (482), o que, mais uma vez, aponta para a interferência do sobrenatural no destino do agora chefe.

A transformação "no cômpito da alma" de Riobaldo também parece responsável pela realização de feitos extraordinários, como a travessia do Liso do Sussuarão, que se julgava impossível até então. Já fora tentada antes, como sabemos, quando o bando tinha como líder Medeiro Vaz, e os resultados foram desastrosos. Coisas terríveis aconteceram durante a tentativa de atravessar o deserto infernal, como no episódio em que um "macaco" - que, revela-se posteriormente, era um homem! - é caçado e comido pelo bando famélico, debilitado e atordoado. A terrível experiência de canibalismo involuntário horrorizou mesmo aqueles homens, acostumados a situações extremas. Os enormes sacrifícios e sofrimentos (físicos e psicológicos) experimentados durante a tentativa frustrada de travessia do Liso podem ter levado, inclusive, ao agravamento do estado de saúde e, ao final, à morte de Medeiro Vaz, que já vinha enfraquecido e pode ter sucumbido, enfim, devido ao esforço empreendido na tentativa frustrada de cruzar o deserto infernal. A partir de então, a situação do bando só se complicou, o que acabou levando Riobaldo a decidir-se por convocar o auxílio das forças maléficas.

Foi depois do possível pacto que o então chefe Urutu Branco conseguiu levar a cabo o desafio e transpor o terrível deserto:

O que era - que o raso não era tão terrível? Ou foi por graças que achamos todo o carecido, nãostante no ir em rumos incertos, sem mesmo se percurar? De melhor em bom, sem os maiores notáveis sofrimentos, sem em-errar ponto. O que era, no cujo interior, o Liso do Suçuarão? - era um feio mundo, por si, exagerado. $\mathrm{O}$ chão sem se vestir, que quase sem seus tufos de capim seco em apraz e apraz, e que se ia e ia, até não-onde a vista não se achava e se perdia. Com tudo, que tinha de tudo. Os trechos de plano calçado rijo: casco que fere faíscas - cavalo repisa em pedra azul. Depois, o frouxo, palmo de areia de cinza em-sobre pedras. E até barrancos e morretes. A gente estava encostada no sol. Mas, com a sorte nos mandada, o céu enuveou, o que deu pronto mormaço, e 
refresco. Tudo de bom socorro, em az. A uns lugares estranhos. Ali tinha carrapato... Que é que chupavam, por seu miudinho viver? Eh, achamos reses bravas - gado escorraçado fugido, que se acostumaram por lá, ou que de lá não sabiam sair; um gado que assiste por aqueles fins, e que como veados se matava. Mas também dois veados a gente caçou - e tinham achado jeito de estarem gordos... Ali, então, tinha de tudo? Afiguro que tinha. Sempre ouvi zum de abelha. O dar de aranhas, formigas, abelhas do mato que indicavam flores. [...]. Todo o tanto, que de sede não se penou demais. Porque, solerte subitamente, pra um mistério do ar, sobrechegamos assim, em paragens. No que nem o senhor nem ninguém não crê: em paragens, com plantas (508).

Como se vê, nessa segunda tentativa, as dificuldades desapareceram. A natureza parece atuar, nessa vez, para que as coisas se dessem da melhor forma possível: "o céu enuveou, o que deu pronto mormaço, e refresco"; os jagunços acharam reses bravas e veados, que puderam caçar e comer; acharam "paragens" onde puderam matar a sede... Depois do suposto pacto, a natureza, ao invés de especialmente hostil, como da primeira vez, forneceu-lhes todo o necessário, de "a" a "z", para a realização de seu intento: proveu-os de "Tudo de bom socorro, em az". E foi justamente a travessia do Liso que permitiu ao bando pegar o inimigo de surpresa do outro lado, capturar a mulher do Hermógenes e, assim, levá-lo à batalha final que culminaria na sua morte.

Contudo, apesar de todos esses indícios, ${ }^{10}$ não há nenhuma evidência inequívoca de que o ambíguo sucesso do empreendimento de vingança contra o Hermógenes ${ }^{11}$ tenha decorrido da realização de um pacto com o demônio. Nem de que as mudanças porquê passou Riobaldo tenham vindo dessa mesma origem. Não há sequer uma evidência definitiva de que um acordo dessa natureza tenha se dado. Quando, entre as páginas 419 e 423, Riobaldo relata o episódio em que tentou realizar o fatídico acordo, relata também que nada de extraordinário aconteceu, nada que comprovasse que um acordo com o sobrenatural estivesse sendo ali selado: o diabo "em pessoa", "solto, por si, cidadão" (10), não compareceu para ratificar o trato, conforme sua expectativa:

$\mathrm{E}$ foi assim que as horas reviraram. - A meia-noite vai correndo... - eu quis falar. $\mathrm{O}$ cote que o frio me apertava por baixo. Tossi, até. - "Estou rouco?" - "Pouco..." - eu mesmo sozinho conversei. Ser forte é parar quieto; permanecer. Decidi o tempo - espiando para cima, para esse céu: nem o setestrelo, nem as três-marias, - já tinham afundado; mas o cruzeiro ainda rebrilhava a dois palmos, até que descendo. A vulto, quase encostada em mim, uma árvore mal vestida; o surro dos ramos. E qualquer coisa que não vinha. Não vendo estranha coisa de se ver.

Ao que não vinha - a lufa de um vendaval grande, com Ele em trono, contravisto, sentado de estadela bem no centro (421).

Riobaldo esperou durante toda a noite, conforme demonstram as mudanças da natureza que marcam a passagem das horas, e nada de extraordinário aconteceu. $\mathrm{O}$ demônio que ele esperava ver, surgindo do meio do redemoinho, não compareceu para ratificar o trato. 
Nem se deram as ocorrências naturais que, segundo as regras de tal acordo na tradição popular do sertão, segundo Riobaldo, celebram o contrato. Ele lista, em outro momento, essas ocorrências:

Se sendo (se o pacto se dá), há-de que vem um pé-de-vento, sem razão, e arre se comparece uma porca com ninhada de pintos, se não for uma galinha puxando barrigada de leitões. Tudo errado, remedante, sem completação... O senhor imaginalmente percebe? O crespo - a gente se retém - então dá um cheiro de breu queimado. $\mathrm{E}$ o dito - o Coxo - toma espécie, se forma! (48).

Nada disso ocorreu. Obviamente, teria pouca chance de algo deste tipo se apresentar num romance que, a despeito de suas matrizes regionais, foi publicado em meados do século XX. Se, por um lado, a utilização da lenda fáustica encontra condições de verossimilhança no ambiente em que a narrativa se desenrola (uma vez que, além de ser uma lenda medieval, também é parte integrante da cultura popular do interior do Brasil) $;^{12}$ por outro, trata-se de um romance moderno, no qual a adesão pura e simples à solução mítico-popular não se sustentaria. Sobre essa questão, Roberto Schwarz (1983, p. 383), em ensaio sobre dois romances modernos que trabalham o motivo do pacto demoníaco - o Grande sertão e o Dr. Faustus, de Thomas Mann -, afirma:

[...] a incorporação da lenda ao século XX tem exigências, e é claro que nossos dois autores não se limitaram a uma reprodução ingênua. Se dão vigência ao mito com relatá-lo, não deixam de suspendê-lo entre aspas, ao fornecer elementos para uma explicação racionalista do que se passa. É essa existência com ressalvas que dá o tom de ambiguidade aos dois livros.

Em Grande sertão: veredas, que interessa especialmente a este estudo, não é possível afirmar que se tenha dado efetivamente um pacto com o demônio; a lenda é utilizada, mas colocada em suspensão, de forma que o que se instaura é a dúvida e a ambiguidade, conforme afirma o crítico. Não só porque o diabo em pessoa não apareceu nem se deram mudanças na natureza que apontassem para uma solução dessa ordem. Riobaldo invoca o demo e, neste momento, pensa fixamente em acabar com o Hermógenes, mas afirma também o seguinte: "e isso figurei mais por precisar de firmar o espírito em formalidade de alguma razão. Do Hermógenes, mesmo, existido, eu mero me lembrava" (421). Essa pode ser uma indicação de que dar cabo do Hermógenes não era o objetivo final do pacto. Como afirmado em outra ocasião:

[...] tudo indica que ele [Riobaldo] tenha buscado a ajuda das forças demoníacas por Diadorim: eliminar o Hermógenes significaria libertar o companheiro da necessidade da vingança de Joca Ramiro para que eles pudessem, juntos, dar novo rumo a suas vidas. Riobaldo já havia proposto ao companheiro que deixassem o banco, e Diadorim, não só não se abalara da determinação de vingar o pai, como se sentira afrontado com a proposta, e cobrava de Riobaldo lealdade e o cumprimento da palavra empenhada. Além disso, o bando atravessava [no período imediatamente anterior ao pacto] situação delicadíssima: por ter de enfrentar, ao mes- 
mo tempo, os hermógenes e os soldados do governo, e, sem líder à altura para conduzi-los nas dificuldades do momento, acabaram se embrenhando e se perdendo nos confins do sertão, e já vagavam há muito tempo sob o comando errático de Zé Bebelo, agora investido da condição de vingador de Joca Ramiro. Riobaldo [...] [então] resolve tomar para si a responsabilidade de solucionar o impasse colocando-se à altura do adversário, que se acreditava pactário. O que ocorre, entretanto, é que, ao alcançar o objetivo intermediário, Riobaldo acaba por destruir a possibilidade de alcançar o objetivo último (SOARES, 2017, p. 172).

Apesar da vitória na batalha do Paredão, a finalidade do pacto não foi alcançada. A entidade sobrenatural não deveria estar conectada com as disposições íntimas do pactário? Não deveria distinguir entre um meio ("acabar com o Hermógenes") e um fim (libertar Diadorim da vingança para que Riobaldo e ele pudessem resolver sua vida)? Isso não colocaria em dúvida a realização do acordo? Ou, ao contrário, seria essa uma artimanha do diabo, que, malignamente, satisfaria o desejo expresso (ou mentalizado) do pactário ao mesmo tempo em que cria obstáculo definitivo para a realização do seu desejo último?

Seja como for, o desfecho da história tem a ver com o que se costuma chamar de ironia trágica. Também discuti aspectos dessa questão no trabalho anteriormente citado:

A ironia trágica da situação está em que essa medida extrema, cujo objetivo final era ter alguma possibilidade de futuro com Diadorim, é que vai privar Riobaldo definitivamente do companheiro. Como o próprio ex-jagunço diz a certa altura, "Assaz o senhor sabe: a gente quer passar um rio a nado e passa; mas vai dar na outra banda é num ponto muito mais em baixo, bem diverso do que em primeiro se pensou. Viver nem não é muito perigoso?” (p.35) Nesse trecho, Riobaldo admite um certo grau de liberdade - é possível atravessar o rio se se toma essa resolução -, o que não é possível é prever a que lugares e situações essa resolução pode levar (SOARES, 2017, p. 172).

Voltando à afirmação de Schwarz de que o livro "fornece elementos para uma explicação racionalista do que se passa", podemos encontrar o mais evidente deles na autossugestão. ${ }^{13}$ Se há uma coisa que podemos afirmar sem receios é que a experiência na encruzilhada das Veredas Mortas teve um forte impacto emocional em Riobaldo. Isso pode tê-lo levado a uma nova disposição íntima, pode ter incutido nele a autoconfiança que ele não tinha antes em suas próprias capacidades.

Assim, poderia ser o diabo "desmascarado como simples travesti de processos individuais", nas palavras de Schwarz (1983, p. 383). Entretanto, subjaz a dúvida: não há como optar por uma e descartar a outra possibilidade, uma vez que há elementos bastante consistentes para apoiar a ambas. Elas se mantêm em tensão irresoluta. Para continuar com as palavras de Schwarz, o demo tem uma "existência com ressalvas que dá o tom de ambiguidade" ao (não)ocorrido. 
O crítico, entretanto, no decorrer de sua argumentação, acaba resolvendo a tensão que o procedimento (de afirmar a explicação sobrenatural e a racional ao mesmo tempo; e ou de problematizar uma pela outra e ainda sustentar as duas) instaura na narrativa ao afirmar que em Grande sertão e Dr. Faustus o diabo é "produto da realidade interpretada" - seja a realidade interpretada pelo narrador "quando procura 'tirar a moral' do seu relato"; ou pelo leitor, que, influenciado pela saturação de informações sobre o tema e pelas sugestões de paralelos misteriosos por parte do narrador, acaba "entregando-se à procura do tinhoso em toda a parte", estabelecendo conexões obscuras por si mesmo ( $\mathrm{SCH}$ WARZ, 1983, p. 384). Ou seja, apesar de ter afirmado anteriormente a tensão instaurada pela utilização e pela suspensão da lenda, Schwarz acaba por resolver a ambiguidade pela afirmação de um sentido final: o demônio é interpretação. Não acreditamos, entretanto, que se possa optar por essa síntese tranquilizadora. Obviamente, nada autoriza a afirmação de que o demônio tenha existência independente da imaginação (ou da interpretação) em Grande sertão: veredas, mas também não se pode afirmar o contrário. O pacto é apresentado como possível no livro. Riobaldo, apesar de algumas vezes fazer afirmações assertivas, é atormentado por dúvidas; bem como o leitor do livro, que se depara com opções entre as quais não há escolha possível, nem a alternativa de uma síntese; só ambiguidade, suspensão de sentido. Como nesse trecho, que ainda se refere ao pacto: "Ele (o demônio) não existe, e não apareceu nem respondeu - que é um falso imaginado. Mas eu supri que ele tinha me ouvido" (422, grifo meu). Nesse trecho, Riobaldo, simultaneamente, nega (é um "falso imaginado) e afirma ("ele tinha me ouvido") a existência do demônio e a possibilidade do pacto. $\mathrm{O}$ enunciado paradoxal provoca um curto circuito de sentido que impossibilita a afirmação de um sentido final. Como afirmou Deleuze (2009, p. 78), o paradoxo "tem por característica o fato de ir em dois sentidos ao mesmo tempo [...], colocando a ênfase ora num ora noutro desses efeitos", o que torna "impossível uma identificação".

A dúvida sobre a existência do demo e, consequentemente, sobre a realização do pacto persiste até o fim, quando, no último parágrafo do livro, o ex-jagunço "assegura”: "o Diabo não há. É o que eu digo, se for" (608, grifo meu). Riobaldo continua a frase afirmando: "o que existe é homem humano", mas o "se for" continua lá, assombrando o sentido pleno, impossibilitando a afirmação do sentido final. 


\section{Suspension and postponement of meaning in Grande sertão: veredas - on the devilish pact}

\section{Abstract}

Riobaldo, the protagonist-narrator of Grande sertão: veredas worries deeply along all the novel about the question of evil and the figure of the devil, and he states more than once that he can talk about such subjects particularly properly. For most of the book, however, he neither explains the main reason why these topics interest him so much nor the reason why he affirms he is so capable of talking about them properly. Riobaldo proposes mysteries and, like in suspense stories, he postpones their solution. Unlike these stories, though, when he at last narrates the episode that would have triggered his worries (his doubtful devilish pact), the "clarification" given is not enough to answer the questions which disturb him. It begets other questions. Thus, the path to elucidation ends up leading to uncertainty and indeterminacy.

Keywords: Grande sertão: veredas. Guimarães Rosa. Suspension and postponement of meaning. Devilish pact. Indeterminacy.

\section{Notas}

Na menção à figura do "bezerro erroso", que, "por defeito como nasceu, arrebitado de beiços, esse figurava rindo feito pessoa. Cara de gente, cara de cão: determinaram - era o demo" (ROSA, 2006, p. 7). De agora em diante, as referências ao romance de Guimarães Rosa virão indicadas no texto somente pelo(s) número(s) de página na edição referida.
2 O Hermógenes parece disforme e desagradável a Riobaldo, segundo ele mesmo, desde a primeira vez em que o viu na fazenda de Selorico Mendes: "O Hermógenes: ele estava de costas, mas umas costas desconformes, a cacunda amontoava, com o chapéu raso em cima, mas chapéu redondo de couro, que se que uma cabaça na cabeça. Aquele homem se arrepanhava de não ter pescoço. As calças dele como que se enrugavam demais da conta, enfolipavam em dobrados. As pernas, muito abertas; mas, quando ele caminhou uns passos, se arrastava - me pareceu - que nem queria levantar os pés do chão" (116-117).

3 É preciso lembrar, entretanto, que Riobaldo está sempre "especulando ideia" (10), vale dizer, refletindo e questionando verdades estabelecidas, o que o leva muito frequentemente a afirmar e, logo a seguir, problematizar, ou mesmo negar, o afirmado, instaurando ambiguidade, indeterminação. Assim, na mesma página, no parágrafo seguinte ao que afirma seu sentimento de não pertença ao grupo, Riobaldo diz: " $\mathrm{E}$ eu era igual àqueles homens? Era” (172). Um dos significados, portanto, está sempre assombrando o outro, e vice-versa - o que impede que o sentido pleno se estabeleça. A impossibilidade do sentido único, unitário, absoluto é uma questão muito importante em Guimarães Rosa, particularmente em Grande sertão: veredas. A esse respeito, cf. Soares (2017).

4 Palavras de outro personagem rosiano em situação, em parte, semelhante. Trata-se de outro proprietário abastado que, também na juventude, se envolveu nas guerras sertanejas, o fazendeiro de "Luas de mel" (ROSA, 1994, p. 463).

$5 \mathrm{Na}$ edição aqui utilizada (ROSA, 2006), que tem, ao todo, 608 páginas.

6 É consenso na crítica rosiana que é neste (não) lugar do "doutor", o interlocutor subentendido de Riobaldo, que se coloca também o leitor do livro.

7 Visão desenvolvida por Cavalcanti Proença, que a altura da publicação do estudo de Candido, já tinha publicado o seu "Trilhas do Grande sertão". Cf. Candido (1983, p. 301), nota 2.

8 No momento imediatamente anterior já tinha se apresentado a inusitada reação dos cavalos diante de Riobaldo e a utilização, por parte dele, da mesma forma de os acalmar. Um pouco antes da chegada de seô Habão, os cavalos do bando se sobressaltam e agitaram quando da 
aproximação do jagunço: "a cavalaria me viu chegar, e se estrepoliu. O que é que cavalo sabe? Uns deles rinchavam de medo [...], e, como não podiam se escapulir para longe, que uns suavam, e já escumavam e retremiam, que com as orelhas apontavam. Assim ficaram, mas murchando e obedecendo, quando, com uma raiva tão repentina, eu pulei para o meio deles: - "Barzabu! Aquieta, cambada!" - que eu gritei. Me avaliaram. Mesmo pus a mão no lombo dum, que emagreceu à vista, encurtando e baixando a cabeça, arrufava a crina, conforme terminou o bufo de bufor" (430).

9 Riobaldo as utiliza em outro contexto, ao referir-se à mudança que se operou em si depois de conhecer e atravessar o São Francisco com Diadorim quando meninos.

10 E esses são somente alguns deles. Não se trata de um levantamento exaustivo, mas é suficiente, acredita-se, para demonstrar o ponto aqui discutido.

11 Ambíguo porque não implicou somente na morte do Hermógenes. O inimigo é destruído ao preço que se sabe: a morte de Diadorim.

12 Assim como o "mundo idealizado da cavalaria", o pacto demoníaco "faz parte indissolúvel da matéria tratada no romance", para utilizar as palavras de Walnice Nogueira Galvão (1986, p. 61), referindo-se ao fato de o sertão brasileiro conservar, ainda que transformados, mitos medievais europeus. O pacto demoníaco é matéria muito comum, ainda hoje, por exemplo, na literatura de cordel e nas canções dos tocadores de viola do norte e noroeste mineiro. Cf. Perreira (2014).

13 Leonardo Arroyo (1984, p. 225-251) vê a mudança de comportamento de Riobaldo depois do pacto como fruto de autossugestão, devido à herança cultural que recebe de seu meio - que, apesar de estar sempre sendo questionada por ele, não deixa de ter sua força sobre o espírito do personagem.

\section{Referências}

ARROYO, Leonardo. A cultura popular em Grande sertão: veredas. Rio de Janeiro: José Olympio, 1984.

AULETE DIGITAL. (Dicionário Caldas Aulete). Disponível em: http://www.aulete.com. br. Acesso em: 29 nov. 2019.
CANDIDO, A. Jagunços mineiros de Cláudio a Guimarães Rosa. In: VÁRIOS escritos. 3. ed. São Paulo: Duas Cidades, 1995. p. 147-179.

CANDIDO, A. O homem dos avessos. In: COUTINHO, Eduardo (org.). Guimarães Rosa. Rio de Janeiro: INL/Civilização Brasileira, 1983. p. 294-309. (Coleção Fortuna Crítica, n. 6).

CEIA, Carlos (coord.). E-Dicionário de Termos Literários (EDTL). Disponível em: https://edtl.fcsh.unl.pt/encyclopedia/suspense/. Acesso em: 29 nov. 2019.

DELEUZE, Gilles. Lógica do sentido. 5. ed. Trad. Luiz Roberto Salinas Fortes. São Paulo: Perspectiva, 2009.

GALVÃO, Walnice Nogueira. As formas do falso. 2. ed. São Paulo: Perspectiva, 1986.

LODGE, David. A arte da ficção. Trad. Guilherme da Silva Braga. Porto Alegre: L\&PM, 2010.

PEREIRA, Luzmar Paulo. As vicissitudes da fama: os dons divinos e os pactos demoníacos entre os tocadores de viola de dez cordas do norte e noroeste mineiro. Revista de Antropologia - USP, São Paulo, v. 55, n. 2, p. 1047-1083, 2014.

ROSA, João Guimarães. Grande sertão: veredas. Rio de Janeiro: Nova Fronteira, 2006.

ROSA, João Guimarães. Primeiras estórias. In: ROSA, João Guimarães. Ficção completa. Rio de Janeiro: Nova Aguilar, 1994. v. 1.

SOARES, Claudia Campos. Ponteando opostos e especulando ideia: Riobaldo e a angústia da falta de sentido. Signo, Santa Cruz do Sul, v. 42, n. 74 , p. 163-173, jun. 2017. Disponível em: https://online.unisc. br/seer/index.php/signo/article/view/7275. Acesso em: 22 nov. 2019.

SCHWARZ, Roberto. Grande sertão: estudos. In: COUTINHO, Eduardo (org.). Guimarães Rosa. Rio de Janeiro: INL/Civilização Brasileira, 1983. p. 294-309. (Coleção Fortuna Crítica, n. 6). 